Vol.27 No.1, June 2021

ISSN (p): 1693-590x, ISSN (e): 2686-4711

DOI: $10.36309 /$ goi.v27i1.145

\title{
Sistem Informasi Akademik di SMK Negeri Jenawi Berbasis Android
}

\author{
Sutariyani* $^{* 1}$, Kristono ${ }^{2}$, Ika Mustika ${ }^{3}$ \\ ${ }^{1,2,3}$ Program Studi Sistem Informasi, STMIK AUB, Surakarta, Indonesia \\ e-mail: *1tari.yani@stmik-aub.ac.id, ${ }^{2}$ kristono@stmik-aub.ac.id, \\ 3ikamustika882@gmail.com
}

\begin{abstract}
Abstrak
Peran guru dalam lingkup sekolah sangatlah penting dalam proses mengajar, maka dari itu setiap selesai pembelajaran siswa diberi tugas, ulangan harian, Ujian Tengah Semester (UTS) maupun Ujian Akhir Sekolah (UAS) untuk mengukur seberapa besar siswa mampu menangkap materi yang diajarkan, melihat hal tersebut akan lebih baik apabila nilai siswa dapat dikelola melalui sistem. Pengelolaan akademik sekolah masih dilakukan secara tertulis berbasis catatan yang belum terpadu, menyebabkan pengulangan data yang mengakibatkan pembukuan tidak efisien. Tujuan dari penelitian adalah untuk membangun dan merancang Sistem Informasi Akademik di SMK Negeri Jenawi Berbasis Android. Hasil perancangan Sistem Informasi Akademik di SMK Negeri Jenawi Berbasis Android ini menggunakan metode pengembangan sistem waterfall. Untuk analisa kelemahan sistem menggunakan analisa PIECES. Sedangkan untuk menggambarkan alur data menggunakan yang terdiri flowchart sistem, usecase diagram, activity diagram, sequence diagram dan class diagram. Bahasa pemrograman yang digunakan adalah Android Studio sedangkan untuk pengolahan database menggunakan MySQL. Hasil dari penilitian ini adalah adanya Sistem Informasi Akademik di SMK Negeri Jenawi Berbasis Android, Sistem ini mempermudah pengolahan data siswa, data guru, mata pelajaran, kelas dan nilai.
\end{abstract}

Kata kunci-Akademik, SMK Negeri Jenawi, Android

\begin{abstract}
The role of the teacher in the scope of the school is very important in the teaching process, therefore every time students finish learning, students are given assignments, daily tests, Mid-Semester Examinations (UTS) and Final School Examinations (UAS) to measure how much students are able to capture the material being taught, see things it would be better if student scores could be managed through the system. School academic management is still carried out in writing based on unified records, causing repetition of data which results in inefficient bookkeeping. The aim of this research is to build and design an Academic Information System at SMK Negeri Jenawi based on Android. The results of the design of the Academic Information System at SMK Negeri Jenawi based on Android use the waterfall system development method. For system weakness analysis using PIECES analysis. Meanwhile, to describe the data flow using a system flowchart, usecase diagrams, activity diagrams, sequence diagrams and class diagrams. The programming language used is Android Studio, while for database processing using MySQL. The result of this research is that there is an Android-based Academic Information System at SMK Negeri Jenawi. This system facilitates the processing of student data, teacher data, subjects, classes and grades.
\end{abstract}

Keywords-Academic, Academic Information System, Android 


\section{PENDAHULUAN}

Kemajuan teknologi saat ini tidak dapat dipisahkan dari kehidupan masyarakat. Berbagai informasi yang terjadi di berbagai belahan dunia kini telah dapat langsung kita ketahui berkat kemajuan teknologi. Dengan demikian untuk penunjang kebutuhan hidup lainnya masyarakat tidak terlepas dari teknologi. Pelayanan sekolah merupakan salah satu aspek penentu kualitas dalam sistem pendidikan. Dalam mendukung suatu keputusan, manajemen sistem informasi dapat dibuat secara maksimal dengan penyampaian data secara cepat [1].

Seiring dengan perkembangan zaman yang sangat luar biasa, ketika teknologi komputer dapat digunakan untuk mendukung penciptaan sistem informasi sekolah dan lingkungan akademik yang ingin mengembangkan sistem pendidikan yang berkualitas dan mencapai sukses, maka diperlukan alat pendukung pengolah data yaitu komputer. Dengan adanya komputer sebagai alat pengolah data, maka semua bidang dalam suatu sekolah ataupun instansi akademis dapat dikomputerisasikan, dalam hal ini bidang-bidang yang dianggap penting dan utama karena hal ini dapat mendukung keberhasilan suatu perusahaan dalam mencapai tujuannya [5].

Peran guru dalam lingkup sekolah sangatlah penting dalam proses mengajar, maka dari itu setiap selesai pembelajaran siswa diberi tugas, ulangan harian, Ujian Tengah Semester (UTS) maupun Ujian Akhir Sekolah (UAS) untuk mengukur seberapa besar siswa mampu menangkap materi yang diajarkan, melihat hal tersebut akan lebih baik apabila nilai siswa dapat dikelola melalui sistem. Adanya sistem dapat membantu pengolahan dari awalnya data mentah diproses menjadi suatu informasi yang akurat, kini lebih cenderung memberi keramahan kepada pengguna. Sehingga dalam mengolah, mengorganisir, dan mengakses data nilai menjadi mudah [2].

Hal ini erat dikaitkan dengan beberapa permasalahan setelah dilakukan observasi di SMK Negeri Jenawi, kelurahan Menjing, Kecamatan Jenawi, kabupaten Karanganyar pada saat pandemi Covid-19. Guru memberikan soal ujian kepada siswa kemudian siswa mengerjakan soal tersebut. Guru menerima lembar jawaban dari siswa kemudian guru mengoreksi lembar jawabannya, setelah itu guru mendapatkan nilai ujian kemudian dicatat dan dibuat laporan rapor untuk diserahkan ke wali kelas. Wali kelas menerima laporan nilai dari guru. Proses selanjutnya laporan nilai juga diserahkan ke kepala sekolah untuk diperiksa. Kemudian nilai tersebut digunakan wali kelas untuk pengisian rapor, rapor telah disetujui wali kelas diserahkan ke kepala sekolah lagi. Rapor telah disetujui oleh kepala sekolah diserahkan ke siswa untuk diberikan ke orang tua atau wali untuk di tandatangani. Rapor yang sudah di tandatangani diberikan kembali ke wali kelas untuk diarsipkan.

Maka dari itu, diperlukan sistem informasi sekolah yang mudah diakses kapan saja dan dimana saja, khususnya bagi siswa dan guru. Sistem informasi akademik berbasis android merupakan salah satu solusi untuk memudahkan siswa dalam mengakses informasi nilai karena banyaknya siswa yang menggunakan android sebagai media informasi. Dari latar belakang masalah tersebut penulis tertarik membuat sistem informasi akademik berbasis android, yang diharapkan akan membantu penyampaian seluruh informasi kepada siswa.

\section{METODE PENELITIAN}

\subsection{Metode Wawancara}

Wawancara digunakan sebagai teknik pengumpulan data apabila peneliti ingin melakukan studi pendahuluan untuk menemukan permasalahan yang harus diteliti, tetapi juga apabila peneliti ingin mengetahui hal-hal dari responden yang lebih mendalam [6].

\subsection{Metode Observasi}

Dalam observasi peneliti terlibat dengan kegiatan sehari-hari orang yang sedang diamati atau yang digunakan sebagai sumber data penelitian [6]. 


\subsection{Metode Pustaka}

Metode ini dilakukan dengan cara membaca atau mempelajari buku-buku referensi literature yang berhubungan dengan masalah yang akan dibahas guna memperoleh landasan teori untuk keperluan menganalisa data [7].

\subsection{Metode Pengujian Sistem Blackbox Testing}

Tahap ini peneliti akan melakukan pengujian menggunakan sekumpulan aktifitas validasi, dengan pendekatan blackbox testing. Blackbox testing adalah menguji perangkat lunak dari segi spesifikasi fungsional tanpa menguji desain dan kode program. Pengujian dimaksudkan untuk mengetahui apakah fungsi - fungsi, masukan, dan keluaran dari perangkat lunak sesuai dengan spesifikasi yang dibutuhkan. Pengujian blackbox dilakukan dengan membuat kasus uji yang bersifat mencoba semua fungsi dengan memakai perangkat lunak apakah sesuai dengan spesifikasi yang dibutuhkan [4].

\subsection{Flowchart Sistem pengolahan data rapor siswa oleh guru}

Flowchart sistem pengolaan data rapor siswa oleh guru yang pada SMK Negeri Jenawi dapat dilihat pada Gambar 1.

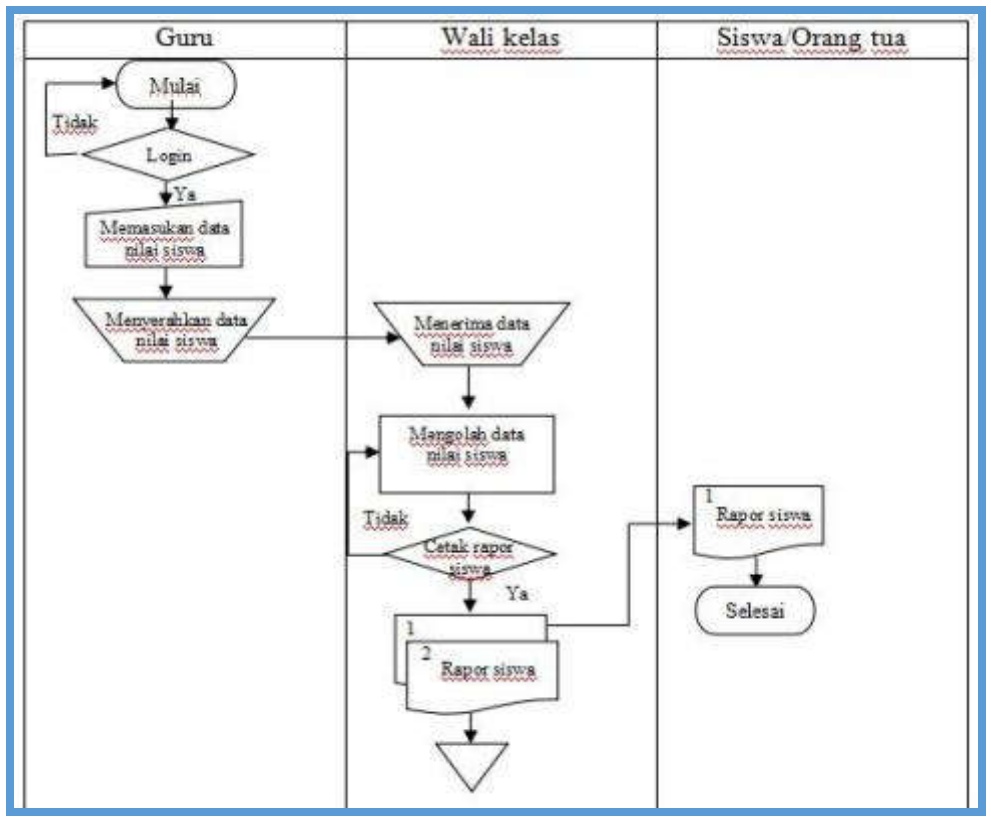

Gambar 1. Flowchart sistem pengolahan rapor siswa oleh guru

Pada Gambar 1, guru melakukan login kedalam sistem, setelah login guru memasukkan data nilai siswa, setelah itu akan diserahkan kepada wali kelas. Oleh wali kelas akan diolah dan ditampilkan kedalam sistem. Kemudian wali kelas mencetak rapor siswa. Kemudian siswa/Orang tua dan wali kelas akan menerima rapor siswa.

\subsection{Flowchart Sistem pengolahan data e-learning yang sudah dibangun}

Flowchart sistem pengolaan data e-learning yang sudah dibangun pada SMK Negeri Jenawi dapat dilihat pada Gambar 2. 


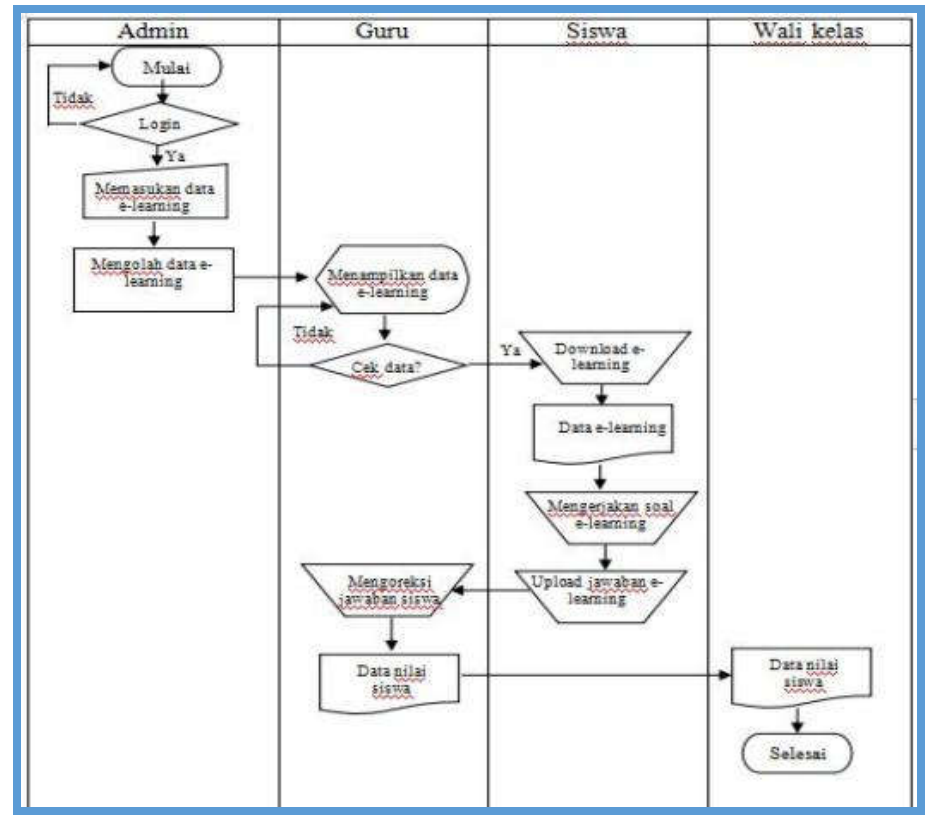

Gambar 2. Flowchart sistem pengolahan data e-learning

Pada Gambar 2, Tata Usaha melakukan login kedalam sistem, kemudian memasukkan data $e$ learning. Selanjutnya data tersebut diolah dan akan di cek oleh Guru. Jika sudag benar selanjutnya data e-learning tersebut akan ditanpilkan pada halaman siswa. Siswa dapat mengunduh data e-learning pada sistem, untuk selanjutnya soal tersebut dikerjakan. Jika sudah selesai siswa mengupload kembali jawaban tersebut untuk dikoreksi guru dan data nilai tersebut akan diserahkan kepada wali kelas.

\subsection{Flowchart Sistem pengolahan jadwal pelajaran siswa oleh tata usaha}

Flowchart sistem pengolaan jadwal pelajaran yang sudah dibangun pada SMK Negeri Jenawi dapat dilihat pada Gambar 3.

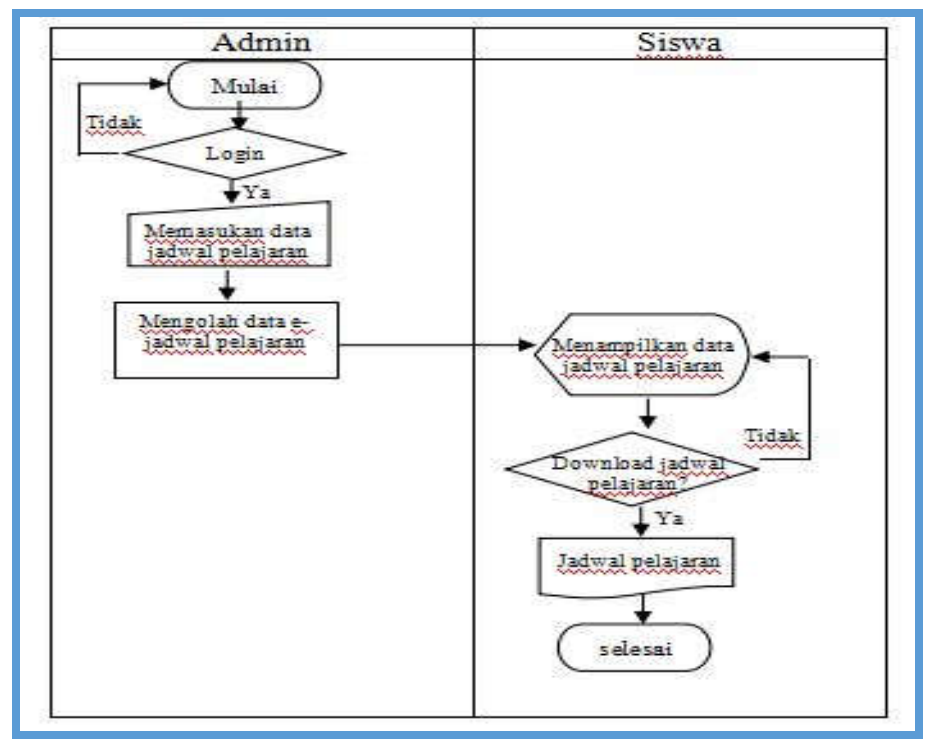

Gambar 3. Flowchart sistem pengolahan jadwal pelajaran siswa oleh tata usaha

Penjelasan Gambar 3, Tata Usaha login kedalam sistem, kemudian admin memasukkan data jadwal pelajaran. Data yang di-input oleh admin akan diolah kedalam sistem kemudian akan 
ditampilkan pada halaman siswa. Siswa dapat men-download jadwal mata pelajaran atau hanya melihat jadwal pelajaran.

\subsection{Flowchart Sistem pengolahan jadwal mengajar guru oleh tata usaha}

Flowchart sistem pengolaan jadwal mengajar guru yang sudah dibangun pada SMK Negeri Jenawi dapat dilihat pada Gambar 4.

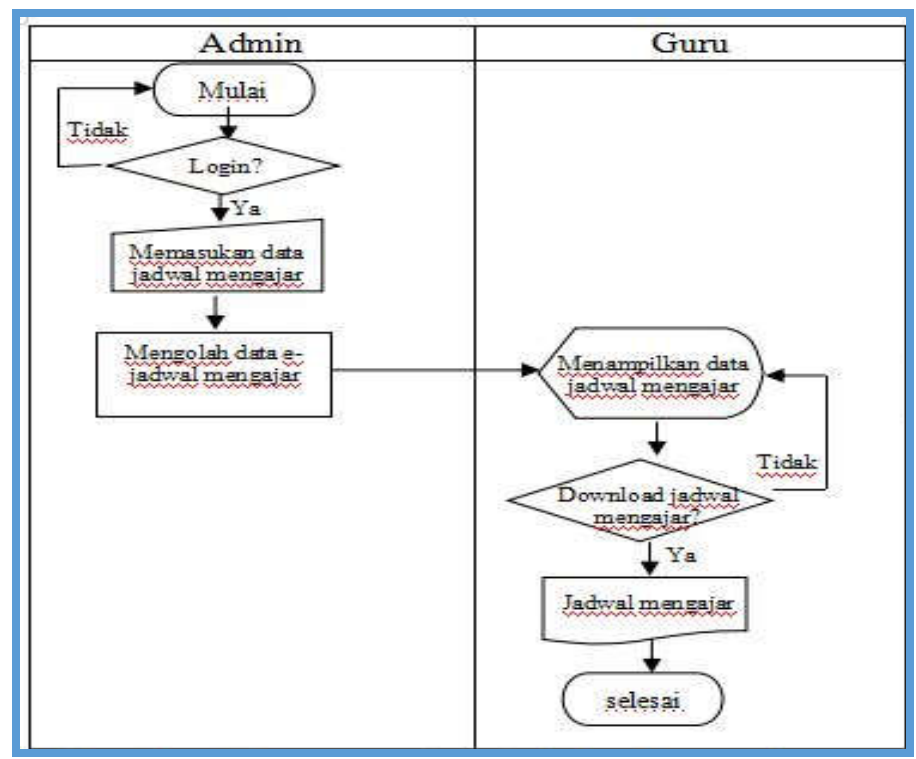

Gambar 4. Flowchart sistem pengolahan jadwal mengajar guru oleh tata usaha

Pada Gambar 4, Admin login kedalam sistem, kemudian admin memasukkan data jadwal mengajar. Data yang di-input oleh admin akan diolah kedalam sistem kemudian akan ditampilkan pada halaman guru. Guru dapat men-download jadwal mengajar atau hanya melihat jadwal mengajar saja.

\subsection{Usecase Diagram}

Use Case Diagram Gambar 5 memperlihatkan himpunan use case dan aktor-aktor. Use case diagram sangat penting untuk mengorganisasi dan memodelkan perilaku dari suatu sistem yang dibutuhkan serta diharapkan pengguna.

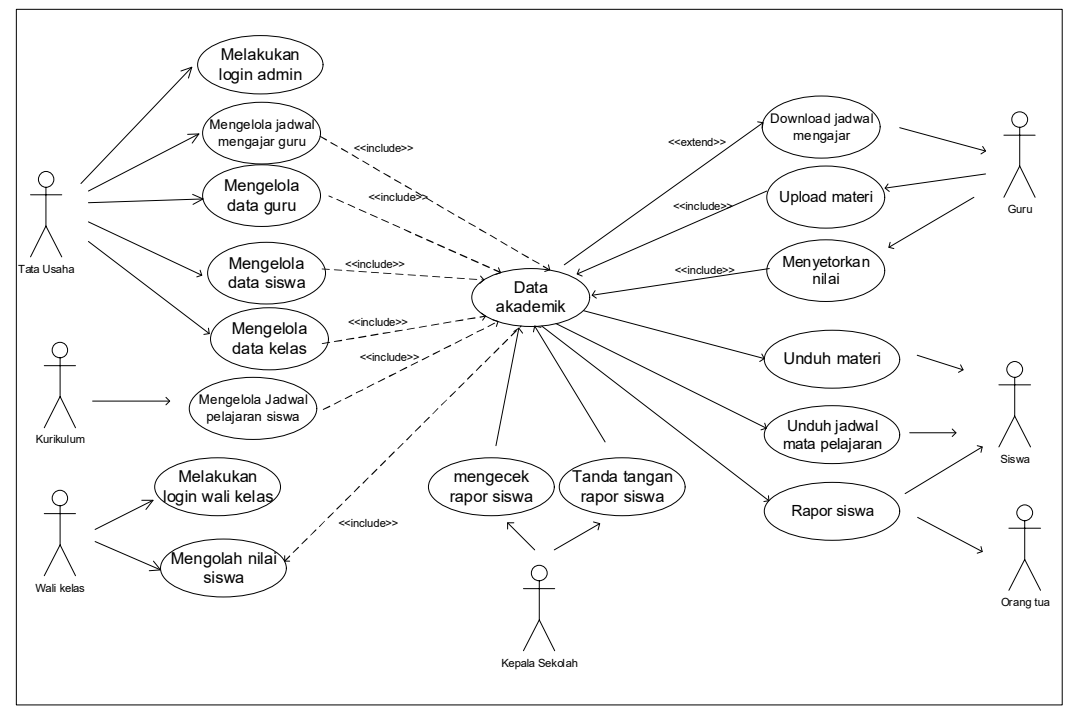

Gambar 5. Usecase diagram 
Tata Usaha melakukan login kedalam sistem untuk dapat mengelola data akademik yaitu data siswa, data guru, data kelas, data nilai, data jadwal mengajar guru, data jadwal mata pelajaran siswa dan data nilai guru. Guru menyerahkan nilai ulangan harian, nilai UTS dan nilai UAS kepada wali kelas untuk diolah dan nantinya akan menjadi rapor siswa. Guru dapat melakukan men-download jadwal mengajar dan upload materi. Sedangkan siswa dapat mengunduh materi, mengunduh jadwal mata pelajaran dan rapor siswa.

\subsection{Activity Diagram}

Activity Diagram adalah Penggambaran rangkaian aliran dari aktivitas, digunakan untuk mendeskripsikan aktifitas yang dibentuk dalam suatu operasi. Dalam Activity diagram Gambar 6 yang dirancang ini terdapat 2 aktor yang terlibat dan memiliki rangkaian aktifitas yang saling berhubungan satu dengan yang lainnya.

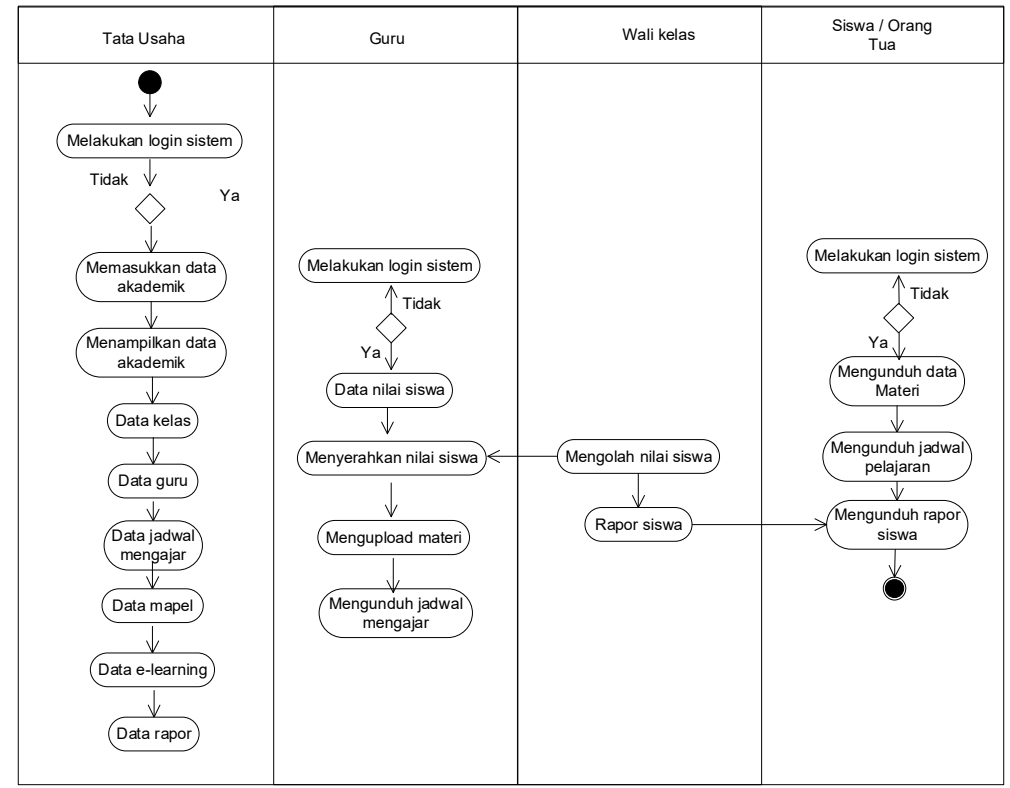

Gambar 6. Activity diagram

Tata Usaha melakukan login kedalam sistem untuk dapat mengelola data akademik yaitu data siswa, data guru, data kelas, data nilai, data jadwal mengajar guru, data jadwal mata pelajaran siswa dan data nilai guru. Guru menyerahkan nilai ulangan harian, nilai UTS dan nilai UAS kepada wali kelas untuk diolah dan nantinya akan menjadi rapor siswa. Guru dapat melakukan men-download jadwal mengajar dan upload materi. Sedangkan siswa dapat mengunduh materi, mengunduh jadwal mata pelajaran dan rapor siswa.

\subsection{Class Diagram}

Class diagram adalah diagram yang digunakan untuk menampilkan beberapa kelas serta paket-paket yang ada dalam sistem/perangkat lunak yang sedang dikembangkan. Class diagram Gambar 7 memberikan gambaran/diagram statis tentang sistem/perangkat lunak dan relasi-relasi yang ada di dalamnya. 


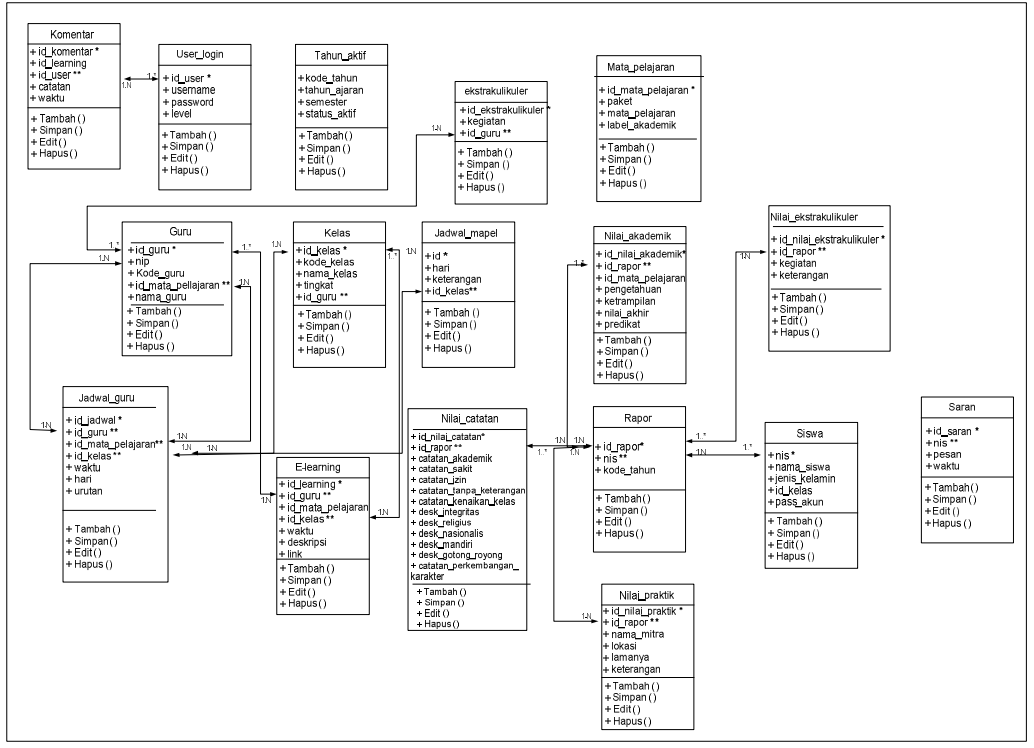

Gambar 7. Class diagram

\section{HASIL DAN PEMBAHASAN}

\subsection{Hasil Implementasi}

Pada bagian ini menguraikan tentang tahapan-tahapan dalam melakukan pengujian terhadap sistem dan program yang sudah selesai dibangun, sehingga sistem tersebut bebas dari kesalahan agar dapat dilanjutkan pada proses selanjutnya yaitu implementasi sistem dengan menggunakan blackbox testing sebagai metode pengujian sistem pada Tabel 1

Tabel 1. Pengujian blackbox testing sistem

\begin{tabular}{|l|l|l|l|l|c|}
\hline No & \multicolumn{1}{|c|}{$\begin{array}{c}\text { Fungsi yang } \\
\text { diuji }\end{array}$} & Data Masukkan & \multicolumn{1}{|c|}{$\begin{array}{l}\text { Hasil yang } \\
\text { diharapkan }\end{array}$} & Pengamatan & Kesimpulan \\
\hline 1 & Tombol masuk & $\begin{array}{l}\text { Admin harus } \\
\text { memasukkan } \\
\text { NIP dan } \\
\text { password untuk } \\
\text { bisa masuk } \\
\text { kedalam aplikasi } \\
\text { sebagai admin. }\end{array}$ & $\begin{array}{l}\text { Sistem dapat } \\
\text { masuk pada } \\
\text { halaman } \\
\text { dashboard } \\
\text { admin }\end{array}$ & Berhasil login. & Benar \\
\hline 2 & $\begin{array}{l}\text { Menu data } \\
\text { kelas }\end{array}$ & $\begin{array}{l}\text { Admin memilih } \\
\text { menu data kelas } \\
\text { untuk mengelola } \\
\text { data kelas }\end{array}$ & $\begin{array}{l}\text { Menampilkan } \\
\text { data kelas }\end{array}$ & $\begin{array}{l}\text { Sistem } \\
\text { berhasil } \\
\text { menampilkan } \\
\text { data kelas }\end{array}$ & Benar \\
\hline 3 & $\begin{array}{l}\text { Tombol } \\
\text { tambah kelas }\end{array}$ & $\begin{array}{l}\text { Admin memilih } \\
\text { tombol Tambah, } \\
\text { untuk } \\
\text { menambah data } \\
\text { kelas baru }\end{array}$ & $\begin{array}{l}\text { Menampilkan } \\
\text { form tambah } \\
\text { kelas }\end{array}$ & $\begin{array}{l}\text { Sistem } \\
\text { berhasil } \\
\text { menyimpan } \\
\text { data kelas }\end{array}$ & Benar \\
\hline 4 & $\begin{array}{l}\text { Menu data } \\
\text { guru }\end{array}$ & $\begin{array}{l}\text { Admin memilih } \\
\text { menu data guru } \\
\text { untuk mengelola } \\
\text { data guru }\end{array}$ & $\begin{array}{l}\text { Menampilkan } \\
\text { data guru }\end{array}$ & $\begin{array}{l}\text { Sistem } \\
\text { berhasil } \\
\text { menampilkan } \\
\text { data guru }\end{array}$ & Benar \\
\hline 5 & $\begin{array}{l}\text { Tombol } \\
\text { tambah guru }\end{array}$ & $\begin{array}{l}\text { Admin memilih } \\
\text { tombol Tambah, } \\
\text { untuk }\end{array}$ & $\begin{array}{l}\text { Menampilkan } \\
\text { form tambah } \\
\text { guru }\end{array}$ & $\begin{array}{l}\text { Sistem } \\
\text { berhasil } \\
\text { menyimpan }\end{array}$ & Benar \\
\hline
\end{tabular}




\begin{tabular}{|c|c|c|c|c|c|}
\hline No & $\begin{array}{c}\text { Fungsi yang } \\
\text { diuji }\end{array}$ & Data Masukkan & $\begin{array}{l}\text { Hasil yang } \\
\text { diharapkan }\end{array}$ & Pengamatan & Kesimpulan \\
\hline & & $\begin{array}{l}\text { menambah data } \\
\text { guru baru }\end{array}$ & & data guru & \\
\hline 6 & $\begin{array}{l}\text { Menu data } \\
\text { mapel }\end{array}$ & $\begin{array}{l}\text { Admin memilih } \\
\text { menu data mata } \\
\text { pelajaran untuk } \\
\text { mengelola data } \\
\text { mata pelajaran }\end{array}$ & $\begin{array}{l}\text { Menampilkan } \\
\text { data mata } \\
\text { pelajaran }\end{array}$ & $\begin{array}{l}\text { Sistem } \\
\text { berhasil } \\
\text { menampilkan } \\
\text { data mata } \\
\text { pelajaran }\end{array}$ & Benar \\
\hline 7 & $\begin{array}{l}\text { Tombol } \\
\text { tambah mapel }\end{array}$ & $\begin{array}{l}\text { Admin memilih } \\
\text { tombol Tambah, } \\
\text { untuk } \\
\text { menambah data } \\
\text { mata pelajaran } \\
\text { baru }\end{array}$ & $\begin{array}{l}\text { Menampilkan } \\
\text { form tambah } \\
\text { mata pelajaran }\end{array}$ & $\begin{array}{l}\text { Sistem } \\
\text { berhasil } \\
\text { menyimpan } \\
\text { data mata } \\
\text { pelajaran }\end{array}$ & Benar \\
\hline 8 & $\begin{array}{l}\text { Menu jadwal } \\
\text { mapel }\end{array}$ & $\begin{array}{l}\text { Admin memilih } \\
\text { menu jadwal } \\
\text { mapel untuk } \\
\text { mengelola } \\
\text { jadwal mata } \\
\text { pelajaran siswa }\end{array}$ & $\begin{array}{l}\text { Menampilkan } \\
\text { jadwal mata } \\
\text { pelajaran siswa }\end{array}$ & $\begin{array}{l}\text { Sistem } \\
\text { berhasil } \\
\text { menampilkan } \\
\text { jadwal mata } \\
\text { pelajaran }\end{array}$ & Benar \\
\hline 9 & $\begin{array}{l}\text { Tombol } \\
\text { tambah jadwal } \\
\text { mapel }\end{array}$ & $\begin{array}{l}\text { Admin memilih } \\
\text { tombol Tambah }\end{array}$ & $\begin{array}{l}\text { Menampilkan } \\
\text { form tambah } \\
\text { jadwal mata } \\
\text { pelajaran }\end{array}$ & $\begin{array}{l}\text { Sistem } \\
\text { berhasil } \\
\text { menyimpan } \\
\text { jadwal mata } \\
\text { pelajaran } \\
\end{array}$ & Benar \\
\hline 10 & $\begin{array}{l}\text { Menu jadwal } \\
\text { guru }\end{array}$ & $\begin{array}{l}\text { Admin memilih } \\
\text { menu jadwal } \\
\text { guru untuk } \\
\text { mengelola } \\
\text { jadwal mengajar } \\
\text { guru }\end{array}$ & $\begin{array}{l}\text { Menampilkan } \\
\text { jadwal mengajar } \\
\text { guru }\end{array}$ & $\begin{array}{l}\text { Sistem } \\
\text { berhasil } \\
\text { menampilkan } \\
\text { jadwal } \\
\text { mengajar }\end{array}$ & Benar \\
\hline 11 & $\begin{array}{l}\text { Tombol } \\
\text { tambah jadwal } \\
\text { mengajar }\end{array}$ & $\begin{array}{l}\text { Admin memilih } \\
\text { tombol Tambah, } \\
\text { untuk } \\
\text { menambah } \\
\text { jadwal mengajar }\end{array}$ & \begin{tabular}{|l|} 
Menampilkan \\
form tambah \\
jadwal mengajar
\end{tabular} & $\begin{array}{l}\text { Sistem } \\
\text { berhasil } \\
\text { menyimpan } \\
\text { jadwal } \\
\text { mengajar }\end{array}$ & Benar \\
\hline 12 & $\begin{array}{l}\text { Menu data } \\
\text { siswa }\end{array}$ & $\begin{array}{l}\text { Admin memilih } \\
\text { menu data siswa } \\
\text { untuk mengelola } \\
\text { data siswa }\end{array}$ & $\begin{array}{l}\text { Menampilkan } \\
\text { data siswa }\end{array}$ & $\begin{array}{l}\text { Sistem } \\
\text { berhasil } \\
\text { menampilkan } \\
\text { data siswa }\end{array}$ & Benar \\
\hline 13 & $\begin{array}{l}\text { Tombol } \\
\text { tambah siswa }\end{array}$ & $\begin{array}{l}\text { Admin memilih } \\
\text { tombol Tambah, } \\
\text { untuk } \\
\text { menambah data } \\
\text { siswa baru }\end{array}$ & $\begin{array}{l}\text { Menampilkan } \\
\text { form tambah } \\
\text { siswa }\end{array}$ & $\begin{array}{l}\text { Sistem } \\
\text { berhasil } \\
\text { menyimpan } \\
\text { data siswa }\end{array}$ & Benar \\
\hline 14 & $\begin{array}{l}\text { Menu data } \\
\text { rapor }\end{array}$ & $\begin{array}{l}\text { Admin memilih } \\
\text { menu data rapor } \\
\text { untuk mengelola } \\
\text { data rapor siswa }\end{array}$ & $\begin{array}{l}\text { Menampilkan } \\
\text { data rapor siswa }\end{array}$ & $\begin{array}{l}\text { Sistem } \\
\text { berhasil } \\
\text { menampilkan } \\
\text { data rapor } \\
\text { siswa } \\
\end{array}$ & Benar \\
\hline 15 & Tombol & Admin memilih & Menampilkan & Sistem & Benar \\
\hline
\end{tabular}




\begin{tabular}{|c|c|c|c|c|c|}
\hline No & $\begin{array}{c}\text { Fungsi yang } \\
\text { diuji }\end{array}$ & Data Masukkan & $\begin{array}{l}\text { Hasil yang } \\
\text { diharapkan }\end{array}$ & Pengamatan & Kesimpulan \\
\hline & $\begin{array}{l}\text { tambah data } \\
\text { rapor }\end{array}$ & $\begin{array}{l}\text { tombol Tambah, } \\
\text { untuk } \\
\text { menambah data } \\
\text { rapor siswa }\end{array}$ & $\begin{array}{l}\text { form tambah } \\
\text { data rapor }\end{array}$ & $\begin{array}{l}\text { berhasil } \\
\text { menyimpan } \\
\text { data rapor }\end{array}$ & \\
\hline 16 & $\begin{array}{l}\text { Tombol } \\
\text { tambah nilai } \\
\text { akademik }\end{array}$ & $\begin{array}{l}\text { Admin memilih } \\
\text { tombol Tambah, } \\
\text { pada halaman } \\
\text { nilai }\end{array}$ & $\begin{array}{l}\text { Menampilkan } \\
\text { form tambah } \\
\text { nilai akademik }\end{array}$ & $\begin{array}{l}\text { Sistem } \\
\text { berhasil } \\
\text { menyimpan } \\
\text { nilai akademik }\end{array}$ & Benar \\
\hline 17 & $\begin{array}{l}\text { Tombol } \\
\text { tambah catatan }\end{array}$ & $\begin{array}{l}\text { Admin memilih } \\
\text { tombol Tambah, } \\
\text { untuk } \\
\text { menambah } \\
\text { catatan belajar } \\
\text { siswa }\end{array}$ & $\begin{array}{l}\text { Menampilkan } \\
\text { form tambah } \\
\text { catatan siswa }\end{array}$ & $\begin{array}{l}\text { Sistem } \\
\text { berhasil } \\
\text { menyimpan } \\
\text { catatan siswa }\end{array}$ & Benar \\
\hline 18 & $\begin{array}{l}\text { Tombol } \\
\text { tambah nilai } \\
\text { praktik }\end{array}$ & $\begin{array}{l}\text { Admin memilih } \\
\text { tombol Tambah, } \\
\text { untuk } \\
\text { menambah nilai } \\
\text { praktik siswa }\end{array}$ & $\begin{array}{l}\text { Menampilkan } \\
\text { form tambah } \\
\text { nilai praktik }\end{array}$ & $\begin{array}{l}\text { Sistem } \\
\text { berhasil } \\
\text { menyimpan } \\
\text { nilai praktik }\end{array}$ & Benar \\
\hline 19 & $\begin{array}{l}\text { Tombol } \\
\text { tambah nilai } \\
\text { ekstrakulikuler }\end{array}$ & $\begin{array}{l}\text { Admin memilih } \\
\text { tombol Tambah, } \\
\text { untuk } \\
\text { menambah nilai } \\
\text { ekstrakulikuler }\end{array}$ & $\begin{array}{l}\text { Menampilkan } \\
\text { form tambah } \\
\text { nilai } \\
\text { ekstrakulikuler }\end{array}$ & $\begin{array}{l}\text { Sistem } \\
\text { berhasil } \\
\text { menyimpan } \\
\text { nilai } \\
\text { ekstrakulikuler }\end{array}$ & Benar \\
\hline 20 & $\begin{array}{l}\text { Menu e- } \\
\text { learning }\end{array}$ & $\begin{array}{l}\text { Admin memilih } \\
\text { menu e-learning } \\
\text { untuk mengelola } \\
\text { data e-learning }\end{array}$ & $\begin{array}{l}\text { Menampilkan } \\
\text { data e-learning }\end{array}$ & $\begin{array}{l}\text { Sistem } \\
\text { berhasil } \\
\text { menampilkan } \\
\text { e-learning }\end{array}$ & Benar \\
\hline 21 & $\begin{array}{l}\text { Tombol } \\
\text { tambah data e- } \\
\text { learning }\end{array}$ & $\begin{array}{l}\text { Admin memilih } \\
\text { tombol Tambah, } \\
\text { untuk } \\
\text { menambah data } \\
\text { e-learning baru }\end{array}$ & $\begin{array}{l}\text { Menampilkan } \\
\text { form tambah } \\
\text { data e-learning }\end{array}$ & $\begin{array}{l}\text { Sistem } \\
\text { berhasil } \\
\text { menyimpan } \\
\text { data e-learning }\end{array}$ & Benar \\
\hline 22 & $\begin{array}{l}\text { Tombol login } \\
\text { user }\end{array}$ & $\begin{array}{l}\text { User } \\
\text { memasukkan } \\
\text { NIS dan } \\
\text { password yang } \\
\text { sebelumnya } \\
\text { didaftarkan pada } \\
\text { aplikasi } \\
\end{array}$ & $\begin{array}{l}\text { Menampilkan } \\
\text { halaman utama } \\
\text { user }\end{array}$ & $\begin{array}{l}\text { Sistem } \\
\text { berhasil masuk } \\
\text { ke halaman } \\
\text { utama aplikasi }\end{array}$ & Benar \\
\hline 23 & $\begin{array}{l}\text { Menu e- } \\
\text { learning }\end{array}$ & $\begin{array}{l}\text { Siswa memilih } \\
\text { menu } e \text { - } \\
\text { learning, untuk } \\
\text { membuka materi } \\
\text { pelajaran }\end{array}$ & $\begin{array}{l}\text { Menampilkan } \\
\text { data e-learning }\end{array}$ & $\begin{array}{l}\text { Sistem } \\
\text { berhasil } \\
\text { menampilkan } \\
\text { data e-learning } \\
\text { siswa }\end{array}$ & Benar \\
\hline 24 & $\begin{array}{l}\text { Tombol detail } \\
\text { e-learning }\end{array}$ & $\begin{array}{l}\text { Setelah memilih } \\
\text { menu e-learning } \\
\text { dan sistem } \\
\text { menampilkan } \\
\text { data e-learning, }\end{array}$ & $\begin{array}{l}\text { Menampilkan } \\
\text { detail data } e \text { - } \\
\text { learning }\end{array}$ & $\begin{array}{l}\text { Sistem } \\
\text { berhasil } \\
\text { menampilkan } \\
\text { informasi } \\
\text { detail data } e \text { - }\end{array}$ & Benar \\
\hline
\end{tabular}




\begin{tabular}{|c|c|c|c|c|c|}
\hline No & $\begin{array}{c}\text { Fungsi yang } \\
\text { diuji }\end{array}$ & Data Masukkan & $\begin{array}{l}\text { Hasil yang } \\
\text { diharapkan }\end{array}$ & Pengamatan & Kesimpulan \\
\hline & & $\begin{array}{l}\text { siswa dapat } \\
\text { melihat data } e- \\
\text { learning secara } \\
\text { detail. }\end{array}$ & & learning & \\
\hline 25 & Menu jadwal & $\begin{array}{l}\text { Siswa memilih } \\
\text { menu jadwal } \\
\text { untuk melihat } \\
\text { jadwal pelajaran }\end{array}$ & $\begin{array}{l}\text { Menampilkan } \\
\text { jadwal mata } \\
\text { pelajaran siswa } \\
\text { secara detail }\end{array}$ & $\begin{array}{l}\text { Sistem } \\
\text { berhasil } \\
\text { menampilkan } \\
\text { jadwal mata } \\
\text { pelajaran } \\
\text { siswa }\end{array}$ & Benar \\
\hline 26 & Menu akun & $\begin{array}{l}\text { Siswa memilih } \\
\text { menu akun } \\
\text { untuk melihat } \\
\text { data akun }\end{array}$ & $\begin{array}{l}\text { Menampilkan } \\
\text { data akun siswa }\end{array}$ & $\begin{array}{l}\text { Sistem } \\
\text { berhasil } \\
\text { menampilkan } \\
\text { informasi akun } \\
\text { siswa }\end{array}$ & Benar \\
\hline 27 & $\begin{array}{l}\text { Menu data } \\
\text { rapor }\end{array}$ & $\begin{array}{l}\text { Siswa memilih } \\
\text { menu data rapor } \\
\text { pada halaman } \\
\text { data akun untuk } \\
\text { melihat rapor } \\
\text { siswa }\end{array}$ & $\begin{array}{l}\text { Menampilkan } \\
\text { informasi nilai } \\
\text { rapor siswa }\end{array}$ & $\begin{array}{l}\text { Sistem } \\
\text { berhasil } \\
\text { menampilkan } \\
\text { informasi nilai } \\
\text { rapor siswa }\end{array}$ & Benar \\
\hline 28 & $\begin{array}{l}\text { Menu } \\
\text { pengaturan }\end{array}$ & $\begin{array}{l}\text { Siswa memilih } \\
\text { menu } \\
\text { pengaturan pada } \\
\text { halaman data } \\
\text { akun untuk } \\
\text { mengubah } \\
\text { password akun } \\
\end{array}$ & $\begin{array}{l}\text { Menampilkan } \\
\text { form ubah } \\
\text { password akun }\end{array}$ & $\begin{array}{l}\text { Sistem } \\
\text { berhasil } \\
\text { menyimpan } \\
\text { password baru } \\
\text { siswa }\end{array}$ & Benar \\
\hline 29 & Menu logout & $\begin{array}{l}\text { Siswa memilih } \\
\text { menu logout } \\
\text { pada halaman } \\
\text { data akun }\end{array}$ & $\begin{array}{l}\text { Menampilkan } \\
\text { informasi untuk } \\
\text { keluar dari } \\
\text { sistem }\end{array}$ & $\begin{array}{l}\text { Sistem } \\
\text { berhasiln } \\
\text { logout }\end{array}$ & Benar \\
\hline
\end{tabular}

\subsection{Hasil Interface}

Gambar halaman login tata usaha dapat dilihat pada Gambar 8.

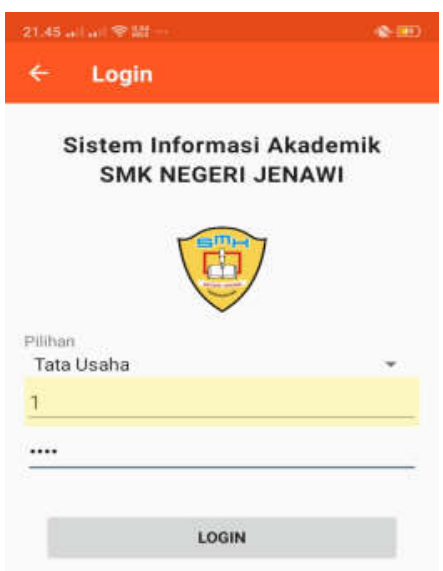

Gambar 8. Halaman Login 
Gambar 8 halaman login tata usaha, menampilkan form login tata usaha yang digunakan untuk masuk kedalam aplikasi sebagai administrator. Tata usaha harus memilih user dan memasukkan password, kemudian klik Login untuk masuk kedalam halaman utama tata usaha. Berikutnya tampilan halaman data menu tata usaha dapat dilihat pada Gambar 9.

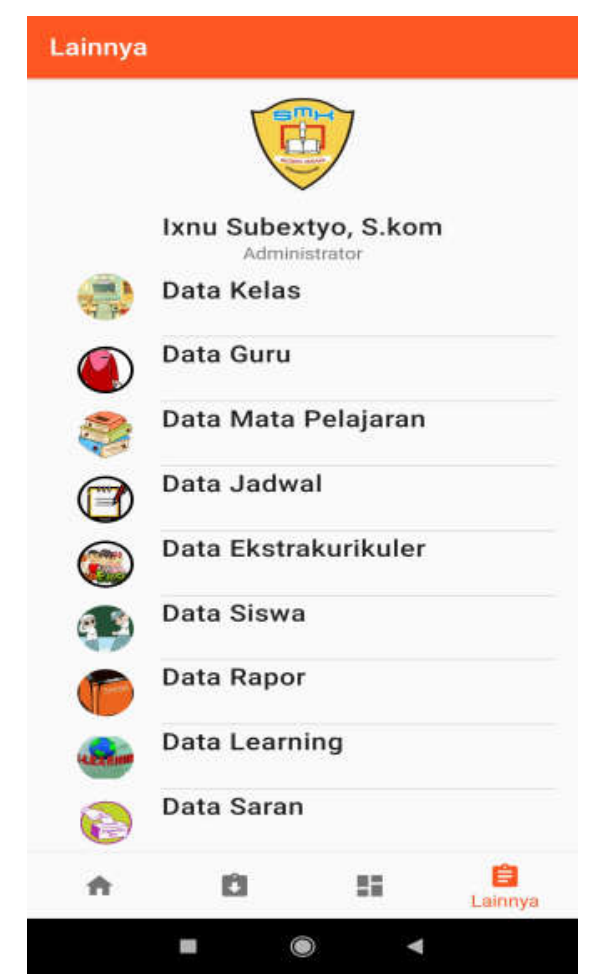

Gambar 9. Halaman data menu tata usaha

Gambar 9 halaman data menu tata usaha menampilkan informasi menu yang akan diolah pada sistem informasi akademik, menu yang ditampilkan yaitu data kelas, data guru, data mapel, jadwal mapel, jadwal guru, data ekstrakulikuler, data siswa, data rapor, data learning, data saran, data pengguna aplikasi. Pada bagian bawah terdapat informasi SMK Negeri Jenawi dan button Logout. Berikutnya tampilan halaman login siswa dapat dilihat pada Gambar 10.

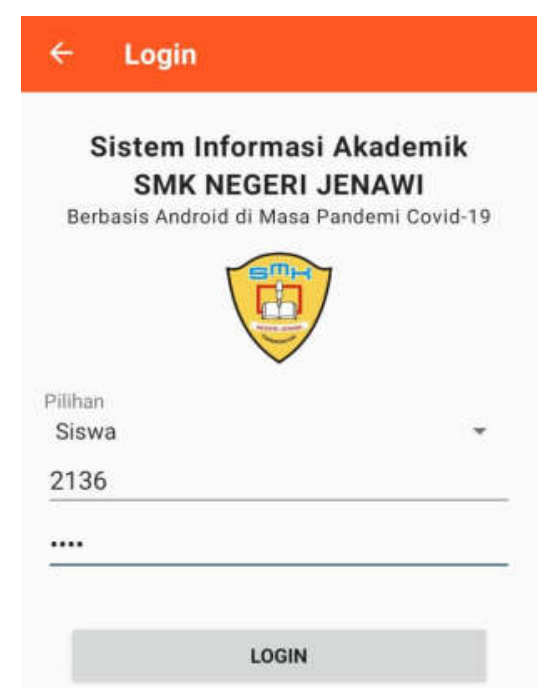

Gambar 10. Halaman Login siswa 
Gambar 10 halaman login siswa menampilkan form login yang berisi username dan password yang digunakan untuk masuk kedalam aplikasi akademik. Siswa hanya perlu memasukkan NIS yang digunakan sebagai username dan password yang sebelumnya sudah didaftarkan, selanjutnya pilih Login untuk masuk kedalam aplikasi. Berikutnya tampilan halaman login Wali kelas dapat dilihat pada Gambar 11.

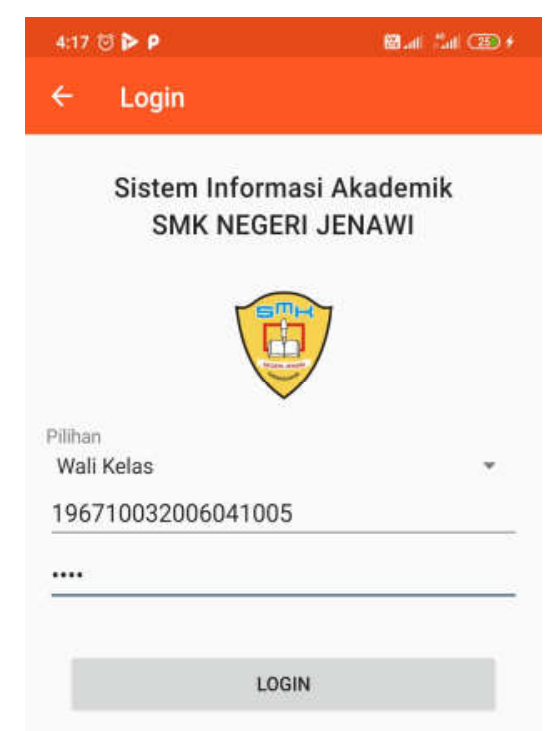

Gambar 11. halaman login Wali Kelas

Gambar 11 halaman login admin, menampilkan form login Wali Kelas yang digunakan untuk masuk kedalam aplikasi sebagai Wali Kelas. Selanjutnya tampilan halaman login guru dapat dilihat pada gambar 12 .

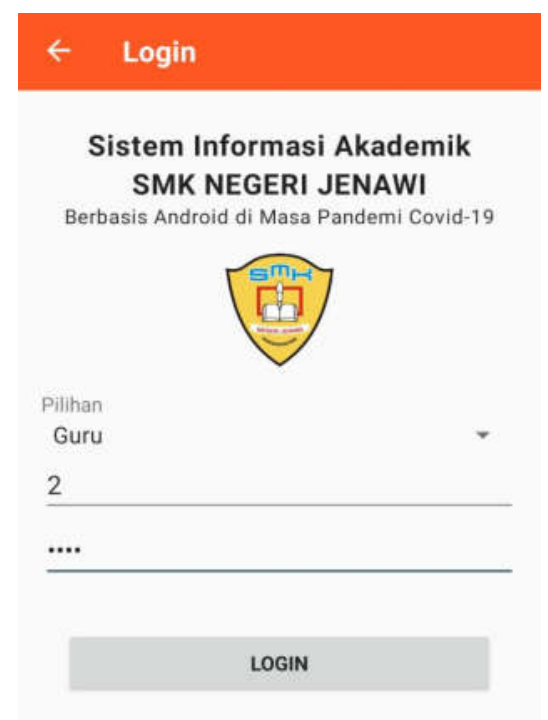

Gambar 12. Halaman login Guru

Gambar 12 halaman login admin, menampilkan form login Guru yang digunakan untuk masuk kedalam aplikasi sebagai Guru. 


\section{KESIMPULAN}

Kesimpulan penelitian sistem informasi akademik di SMK Negeri Jenawi berbasis Android, dapat digunakan untuk mempermudah pengolahan data akademik yang terdiri dari data siswa, data guru, mata pelajaran, kelas dan nilai. Perancangan sistem informasi akademik SMK Negeri Jenawi berbasis Android menggunakan Android Studio 4.2. Sedangkan untuk pengolahan database menggunakan MySQL.

\section{SARAN}

Sistem Informasi Akademik di SMK Negeri Jenawi Berbasis Android, masih dapat dikembangkan lebih lanjut, yaitu adanya penambahan menu untuk melakukan pendaftaran siswa baru secara online.

\section{DAFTAR PUSTAKA}

[1] Fonna, N. 2019. Pengembangan Revolusi Industri 4.0 dalam Berbagai Bidang. Guepedia.

[2] Kharisma, N. 2015. Pengaruh Motivasi, Prestasi Belajar, Status Sosial Ekonomi Orang Tua Dan Lingkungan Teman Sebaya Terhadap Minat Melanjutkan Pendidikan Ke Perguruan Tinggi Pada Siswa Kelas Xii Kompetensi Keahlian Akuntansi Di Smk Negeri Se-Kota Semarang Tahun Ajaran 2014/2015 (Doctoral Dissertation, Universitas Negeri Semarang).

[3] Mulyatiningsih, E. 2016. Pengembangan model pembelajaran. Diakses dari http://staff. uny. ac. id/sites/default/files/pengabdian/dra-endang-mulyatiningsih$\mathrm{mpd} / 7$ cpengembangan-model-pembelajaran. pdf. pada September.

[4] Rosa a.s, M.Shalahuddin. 2015. Rekaya Perangkat Lunak. Jakarta: PT Elex Media Komputindo.

[5] Simarmata, Janner, Choms Gary Ganda Tua Sibarani, and Tauada Silalahi. 2019. Pengembangan Media Animasi Berbasis Hybrid Learning. Yayasan Kita Menulis.

[6] Sugiyono. 2012. Metode Penelitian Kuantitatif, Kualitatif Dan r\&d. Bandung: Alfabeta.

[7] Usman, Husaini dan Setiady Akbar, R. Purnomo 2000; Pengantar Statiska, PT. Bumi Aksara, Jakarta. 